Profit: Jurnal Kajian Ekonomi dan Perbankan 2 (1) 2018. P: 50-61

PROFIT : JURNAL KAJIAN EKONOMI DAN PERBANKAN

https://ejournal.unuja.ac.id/index.php/profit

E-ISSN : 2597-9434, ISSN: 26854309

\title{
DAMPAK BISNIS ONLINE TERHADAP FLUKTUASI PENJUALAN DI KOPERASI DALEM SELATAN (KDS) KAMILAH WILAYAH FATIMATUZZAHRO' PONDOK PESANTREN NURUL JADID
}

\author{
Najiburrahman Wahid \& Nur \\ Halima*
}

- Univiversitas Nurul Jadid

This research is motivated by the development of times that are very rapid and increasingly modern so as to provide a boost to system changes both in terms of transactions, sales and marketing. The rise of virtual commerce or what is often called Online Business has a big influence on trade in the real world, as happened in our KDS in the Fathimatuzzahra 'PP region. Nurul Jadid. Before the online business that entered the KDS pesantren we experienced an increase in sales. However, after the existence of an online business that is increasingly prevalent in boarding schools causing fluctuations in sales at KDS, we are.This research was carried out to find out: (1) the impact that arises with the existence of an online business against fluctuations in sales in the KDS cooperative. (2) Steps of KDS cooperatives We are in maintaining consumer interest.Online business is a business whose trade is connected through the internet network. Sales fluctuations are the rate of dynamic change in the supply or production of producer goods within a certain period of time. Whereas KDS We are a business unit of pesantren which is different in nature from kopresai in general. This research is a type of qualitative research. This study chose a business unit in the Fatimatuzzahro region in the Nurul Jadid Islamic Boarding School. The technique of collecting data uses observation, interviews and documentation. The 
validity of the data is tested by triangulation. Data analysis techniques in the form of data collection, data reduction, data presentation and conclusion. After carrying out the research, the researcher concluded that the impact arising from the proliferation of Online sales was the decrease in KDS income. We were based on the monthly sales report of KDS. We were. and the steps taken to overcome the problem of decreasing income in our KDS are by increasing the promotion strategy, lottery coupons and price discounts.

Email :

Keyword:Online bussines, Sales Fluctuations and peer support 


\section{PENDAHULUAN}

Perkembangan dalam dunia era globalisasi semakin pesat dengan adanya teknologi yang semakin canggih.Inovasi-inovasi terus dilahirkan guna mempermudah pekerjaan manusia.Dalam bidang teknologi dan informasi ditandai dengan adanya jaringan internet yang saat ini telah tersebar keseluruh dunia.Dengan semakin majunya teknologi internet dan semakin banyaknya masyarakat yang menggunakan teknologi ini telah menciptakan berbagai konsekuensi, antara lain peningkatan ketergantungan terhadap teknologi internet.

Internet menyediakan berbagai macam media sosial yang dapat memudahkan untuk mendapatkan setiap informasi yang di butuhkan sesuai kebutuhan. Penggunaan internet dalam bisnis berubah dari fungsi sebagai alat untuk pertukaran informasi secara elektronik menjadi alat untuk aplikasi strategi bisnis, seperti: pemasaran, penjualan, dan pelayanan pelanggan. ${ }^{1}$

Bisnis online biasanya menggunakan media Online berupa jaringan internet. Media ini bisa disebut dengan via Online.Online telah dikenal dari berbagai kalangan usia, mulai dari remaja sampai dewasa. Perkembangan bisnis Onlinemelalui internet semakin meningkat, Dengan tersebarnya jaringan internet keseluruh dunia menjadikan Online ini semakin berkembang. ${ }^{2}$

Perkembangan bisnisOnline ini turut memberikan dampak kepada unit usaha yang berada dalam ruang lingkup masyarakat yang biasa dikenal dengan sebutanKoperasi. Koperasi mulai tumbuh dan berkembang di Inggris pada pertengahan abad XIX yaitu sekitar tahun 1844 yang dipelopori oleh Charles Howard di Kampung Rochdale.Koperasi merupakan badan usaha masyarakat/badan tertentu yang dikelola dalam daerah tertentu untuk mensejahterakan anggota melalui asas-asas Koperasi.Namun secara resmi gerakan koperasi di Indonesia baru lahir pada tanggal 12 juli 1947 pada KongresI di Tasikmalaya yang di peringati sebagai hari Koperasi Indonesia.

Koperasi yang letaknya berada dalam ruang lingkup pesantren khususnya Pesantren Nurul Jadid di Wilayah Fathimatuzzahro' bernama Koperasi KDS Kamilah.Koperasi KDS Kamilah merupakan unit usaha pesantren yang sifatnya berbeda dengan koperasi pada umumnya. Karena Koperasi KDS Kamilah hanya menjual aneka kebutuhan santri seperti peralatan make

\footnotetext{
${ }^{1}$ Oviliani Yenty Yuliana, 'PENGGUNAAN TEKNOLOGI INTERNET', 2.1 (2000), hal 37.

${ }^{2}$ Sholihatin Nurul Jannah, 'Analisis Open Order Dan Close Order Terhadap Minat Beli Produk Online Shop Studi Pada SNJCOLLECTION', Kompetensi, 11.2 (2017), 245.
}

$52 \quad$ Profit : Jurnal Kajian Ekonomi dan Perbankan 
up, aneka tekstile, hijab dll. Koperasi KDS Kamilah tidak menggunakan sistem bagi hasil namun keuntungan disetorkan kepada pihak pesantren.

Dalam hal ini peneliti sangat tertarik untuk meneliti dampak yang muncul dengan adanya bisnis Online terhadap fluktuasi penjualan di Koperasi Dalem Selatan (KDS) Kamilah yang ada di wilayah Fatimatuzzahro'. Serta langkah- langkah Koperasi Dalem Selatan (KDS) Kamilah dalam mempertahankan minat konsumen.

\section{TEORI}

Bisnis adalah suatu pertukaran barang, jasa, atau uang yang saling menguntungkan atau memberi manfaat. Bisnis juga memilki makna sebagai“the buying and salling of goods and services".Bisnis merupakan suatu istilah yang menjelaskan bahwa segala aktivitas berbagai institusi dari yang menghasilkan barang atau jasa yang perlu untuk kehidupan masyarakat sehari-hari.Secara umum bisnis diartikan sebagai suatu kegiatan yang dilakukan oleh manusia untuk memperoleh pendapatan, penghasilan atau rizki dalam rangka memenuhi suatu kebutuhan dan keinginan hidupnya dengan cara mengelola sumber daya ekonomi secara efektif dan efisien yang memberikan pengaruh terhadap berlangsungnya kehidupan ekonomi.Adapun sektor-sektor ekonomi bisnis tersebut meliputi sektor pertanian, sektor industri, jasa, dan perdagangan.

Bisnis berlangsung karena adanya kebergantungan antar individu, adanya peluang internasional, usaha untuk mempertahankan dan meningkatkan standar hidup, dan lain sebagainya.Bisnis juga di pahami dengan suatu kegiatan usaha individu (privat) yang terorganisasi atau melembaga, untuk menghasilkan dan menjual barang atau jasa guna mendapatkan keuntungan dalam memenuhi kebutuhan masyarakat. ${ }^{3}$ Menurut Huat, $\mathrm{T}$ Chwee (1990) bisnis dalam arti luas adalah istilah umum yang menggambarkan semua aktifitas dan institusi yang memproduksi barang dan jasa dalam kehidupan sehari- hari. ${ }^{4}$ Menurut Adam Smith tujuan utama suatu bisnis sesungguhnya bukan hanya untuk mencari keuntungan melainkan untuk memenuhi kebutuhan hidup orang lain, dan melalui bisnis orang lain bisa memperoleh apa yang di butuhkannya. ${ }^{5}$

\footnotetext{
${ }^{3}$ Muhammad Djakfar, Hukum Bisnis: Membangun Wacana Integrasi Perundangan Nasional Dengan Syariah (UIN-Maliki Press, 2016) 25.

4 Budi Mulyadi“" Budaya Dan Etika Bisnis Masyarakat Jepang” Jurnal Kiryoku, Vol. 1, No. 3, $2017,2$.

${ }^{5}$ Ismu Fadli Kharis, 'Studi Mengenai Impulse Buying Dalam Penjualan Online', Skripsi. Semarang: Universitas Diponegoro, 2011, hal 40.
} 
Bisnis juga mempunyai suatu etika Kata etika berasal dari bahasa Yunani yaitu "ethos" yang mempunyai arti : adat, akhlak, watak, persaan, sikap dan cara berpikir atau berarti adat sitiadat. Dapat dikatakan pula bahwa, Etika adalah filsafat tentang nilai-nilai, kesusilaan tentang baik dan buruk.

Bagi umat islam yang melakukan bisnis secara islam dan selalu berpegang teguh pada norma-norma hukum islam, maka akan mendapatkan berbagai manfaat diantaranya: ${ }^{6}$

Bahwa bisnis dalam Islam dapat bernilai sosial atau tolong menolong terhadap sesama, akan menumbuhkan berbagai pahala.Berbisnis secara islam merupakan salah satu cara untuk menjaga kebersihan dan halalnya barang yang di konsumsi untuk dirinya dan pembeli.Berbisnis secara jujur, sabar, ramah dan pelayanan yang baik.Bisnis secara islam merupakan cara untuk memberantas kemalasan, pengangguran dan pemerasan kepada orang lain.

Secara umum Online menunjukkan keadaan terhubung ke internet. Online dikenal dan digambarkan sebagai perdagangan elektronik. Perdagangan elektronik atau e-dagang (bahasa Inggris: Electronic commerce, atau biasa di sebut e-commerce) adalah penyebaran, pembelian, penjualan, pemasaran barang dan jasa melalui sistem elektronik. Istilah e-commerce mengacu pada sebuah transaksi yang dilakukan melalui sebua media elektronika seperti internet, yang meliputi web, internet, dan extranet. ${ }^{7}$

Kata Online tidak akan lepas dengan internet, dalam artian orang yang hendak melakukan bisnis secara Online haruslah tersambung ke internet hotspot. Dengan adanya jasa online pembisnis bisa dengan mudah memasarkan produknya kapan saja dan dimana saja, tanpa harus berpanas-panasan.Online merupakan proses pembelian dan penjualan produk, jasa dan informasi yang dilakukan secara elektronik dengan memanfaatkan jaringan komputer. ${ }^{8}$

Fluktuasi mempunyai arti gejala yang menunjukkan turun naiknya suatu.Fluktuasi penjualan adalah kenaikan dan penurunan aktivitas penjualan secara relatif dibandingkan dengan tren pertumbuhan jangka panjang dari penjualan.

Adapun faktor yang mempengaruhi terjadinya fluktuasi penjualan ialah sebagai berikut: Nominal harga yang ditentukan produsen agen tidak stabil, Persediaan barang kurang

\footnotetext{
${ }^{6}$ Shobirin, "Jual Beli dalam Pandangan Islam" Bisnis Jurnal dan Manajemen Islam, Vol. 3, No. 2, Desember 2015, 259.

'Imam Mustofah, "Transaksi Elektronik (E-Commerce) dalam Perspektif Fikih", Jurnal Hukum Islam, Vol.10, No.2, Desember 2012, 159-160.

${ }^{8}$ Rosian Anwar 1 Wijaya Adidarma 2, 'PENGARUH KEPERCAYAAN DAN RISIKO PADA MINAT BELI BELANJA ONLINE', Jurnal Manajemen Dan Bisnis Sriwijaya, 14.2 (2016), 155.
}

$54 \quad$ Profit : Jurnal Kajian Ekonomi dan Perbankan 
terpenuhi, Barang yang diperjual belikan kurang diminati oleh konsumen, Kualitas barang yang diperjual belikan kurang menarik.

Karena penyebab dari faktor-faktor tersebut maka terjadinya fluktuasi penjualan yang memberikan dampak terhadap pendapatan produsen.

Pengertian koperasi berasal dari bahasa Inggris co-operation yang berarti usaha bersama. Namun meski demikian dengan yang dimaksud dengan koperasi disini adalah suatu bentuk unit usaha koperasi yang didirikan oleh pesantren untuk melakukan kegiatan jual beli untuk memenuhi kebutuhan santri yang berada dilingkungan pesantren.Koperasi pesantren adalah suatu induk usaha untuk kesejahteraan bersama. ${ }^{9}$

Koperasi adalah unit usaha yang dikelola oleh pengurus pesantren dalam upaya memperkuat perekonomian pesantren dan dibentuk berdasarkan kebutuhan dan potensi pesantren. Koperasi merupakan salah satu bentuk perwujudan dari konsep saling menolong (ta'awun), persaudaraan (ukhuwah), menuntut ilmu (tholabbul ilmi) dan berbagai aspek ajaran islam lainnya. Konsep bersama-sama (berjama'ah) dan dijalankan secara hukum yang jelas dan adil (syariah) yang relevan dengan tujuan koperasi yang didirikan, dikelola syah dengan ketentuan peraturan bersama dan sejahtera untuk anggota secara bersama.

Koperasi juga mempunyai suatu potensi, Potensi adalah kemampuan yang mempunyai kemungkinan untuk dikembangkan.Maksud dalam pengertian diatas ialah sesuatu yang memiliki kemampuan untuk dapat dikembangkan sehingga menghasilkan sesuatu yang bernilai. ${ }^{10}$

Adapun faktor-faktor yang menghambat dalam pertumbuhan koperasi : ${ }^{11}$

\section{a. Finansial (keuangan)}

Keuangan mempelajari bagaimana individu, bisnis, dan organisasi meningkat, mengalokasi, dan menggunakan sumber daya moneter sejalan dengan waktu, dan juga menghitung risiko dalam menjalankan suatu unit usah (koperasi).

b. Manajerial (Keahlian Manajemen)

\footnotetext{
${ }^{9}$ Sri Pangetuti, Adhi Iman Sulaiman, M. Maslukin, C. Chusmeru, 'Pemberdayaan Koperasi Pondok Pesantren Sebagai Pendidikan Sosial Dan Ekonomi Santri', Pendidikan Dan Pemberdayaan Masyarakat, 3.November (2016), 3.

${ }^{10}$ Marilna "Potensi Pesantren Dalam Pengembangan Ekonomi Syariah" Jurnal Hukum Islam, Vol, 12. No, 1.Juni 2014, 133.

${ }^{11}$ Andika Chandra and S R R Retno, 'KECIL PADA SEKTOR FORMAL DAN INFORMAL DI JAWA TIMUR', Bisnis, Program Manajemen Manajemen, Program Studi Petra, Universitas Kristen Petra, 2.1 (2014). 
Kompetensi manajerial merupakan gabungan dari pengetahuan, kemampuan, perilaku dan sikap yang dipakai dalam bekerja secara efektif.

c. Lokasi Dan Jaringan

Lokasi memiliki dampak pada potensi unit usaha dan peluang pertumbuhan suatu unit usaha.Lokasi mempengaruhi keunggulan kompetitif melalui pengaruhnya terhadap produktivitas.

d. Ekonomi

Faktor ekonomi memiliki dampak pada potensi daya tarik dari berbagai strategi dan pola konsumsi dalam perekonomian serta memiliki efek yang signifikan terhadap organisasi di berbagai industri dan di berbagai lokasi.

e. Tenaga Kerja

Unit usaha memerlukan akses yang sesuai untuk keterampilan dan tenaga kerja yang bermotivasi dalam mempertahankan pertumbuhan dam memiliki loyalitas.

Semakin banyaknya para pembisnis sehingga Memahami konsumen saja tidak cukup bagi manajer pemasaran untuk masa sekarang.Bisnis-bisnis harus bekerja lebih keras untuk merebut pasar.Akibatnya bisnisbisnis tersebut juga mulai memperhatikan para pesaingnya di samping tetap berusaha memahami konsumen.Maka Analisis pesaing sangat diperlukan bagi efektifitas pemasaran.Karena dari perkembangan dunia industri semakin pesat, beraneka ragam usaha dibuka dengan leluasa. ${ }^{12}$

\section{METODE PENELITIAN}

Jenis penelitian yang digunakan adalah penelitian lapangan (field research) dalam penelitian ini penulis menggali data dengan turun langsung kelapangan untuk meneliti gambaran dampak bisnis Online terhadap fluktuasi penjualan koperasi KDS Kamilah di wilayah Fatimatuzzahro'. Metode yang digunakan dalam penelitian ini adalah metode kualitatif.Metodelogi penelitian kualitatif adalah berupa prosedur pengumpulan data secara sistematis dan intensif untuk menghasilkan data deskriptif berupa kata-kata tertulis atau lisan dari orang-orang dan perilaku yang dapat diamati.Yang bermaksud membuat deskripsi mengenai situasi-situasi dan kejadian secara sistematis, faktual dan akurat. Alasan penulis menggunakan

\footnotetext{
${ }^{12}$ Moh Idil Ghufron and Inas Fahmiyah, 'KONSEP WARALABA PERSPEKTIF EKONOMI ISLAM', Amwaluna: Jurnal Ekonomi Dan Keuangan Syariah, 3.1 (2019). 
metode kualitatif sesuai dengan pendapat John W. Creswell memilih studi kualitatif karena hakikat dari pertanyaan penelitian dalam studi kualitatif, pertanyaan penelitian sering dimulai dengan bagaimana atauapa. Dengan demikian, permulaan tersebut memaksa masuk ke dalam topik yang mendiskripsikan apa yang sedang berlangsung. ${ }^{13}$

\section{HASIL PENELITIAN}

Wilayah Fathimatuzzahro' adalah salah satu wilayah yang ada di Pondok Pesantren Nurul Jadid disebelah selatan pesantren yang menempati lahan kurang lebih $1.500 \mathrm{~m} 2$.Wilayah Fatimatuzzahro' didirikan pada tahun 1975 oleh almarhum KH.Hasan Abdul Wafie yang dalam kepengasuhannya dibantu oleh istri beliau $\mathrm{Ny} \mathrm{Hj}$. Aisyah Zaini.Seiring dengan berjalannya waktu dan perkembangan tekhnologi serta tuntutan kebutuhan santri yang semakin meningkat ditengah pelayanan yang dituntut optimal maka Wilayah Fathimatuzzahro' menyediakan koperasi, sebagai salah satu upaya untuk memenuhi kebutuhan santri.

Nama "Kamilah" sendiri merupakan sebuah nama yang diberikan langsung oleh koordinator pengurus Wilayah Fatimatuzzahro'. Karena beliau mengharapkan semua program yang diterapkan di koperasi tersebut bisa berjalan dengan lancar dan sempurna. Karena makna dari kata "Kamilah" sendiri adalah sempurna.

Unit Usaha Koperasi Dalem Selatan (KDS) Kamilah terletak di Pondok Pesantren Nurul Jadid tepatnya di Wilayah Fathimatuzzahro' Desa Karanganyar Kecamatan Paiton Kabupaten Probolinggo, sekitar $27 \mathrm{~km}$ ke arah timur pusat kota Probolinggo atau $4 \mathrm{~km}$ dari Pusat Pembangkit Listrik Tenaga Uap (PLTU) Paiton ke arah barat, dengan menempati lahan seluas 96 $\mathrm{m}^{2}$. Unit Usaha Koperasi Dalem Selatan (KDS) Kamilah merupakan bagian yang tak terpisahkan dari Wilayah Fathimatuzzahro' Pondok Pesantren Nurul Jadid Paiton Probolinggo dengan menempati lahan seluas $22.510 \mathrm{Ha}$.

\footnotetext{
${ }^{13}$ J Moleong Lexy, 'Metodologi Penelitian Kualitatif', Bandung: Remaja Rosdakarya, 2002, 177.

57 Profit : Jurnal Kajian Ekonomi dan Perbankan
} 
Adapun jumlah keseluruhan santri di Wilayah Fathimatuzzahro' sebagai berikut:

\begin{tabular}{|c|c|c|}
\hline NO & KATEGORI SANTRI & JUMLAH \\
\hline 1 & SISWI & 209 \\
\hline 2 & MAHASISIWI & 107 \\
\hline & JUMLAH & 316 \\
\hline
\end{tabular}

Tabel 1. Jumlah Keseluruhan Santri Wilayah Fathimatuzzahro'

Fluktuasi dapat dimaknai sebagai gejala kenaikan dan penurunan suatu aktivitas usaha pada bidang penjualan/bisnis secara relatif dibandingkan dengan tren pertumbuhan jangka panjang penjualan.Pilihan tersebut didasarkan pada pengamatan, evaluasi, kriteria produk dan jumlah konsumen. Kriteria pemilihan dalam memutuskan untuk membeli atau mengkonsumsi barang didasarkan pada pertimbangan dalam harga, kelas produk, kenyamanan, kecepatan pelayanan, jumlah variasi produk dan sebagainya.

Penyebab terjadinya suatu fluktuasi karena disebabkan beberapa faktor, diantaranya sebagai berikut :

a. Barang yang diperjual belikan kurang diminati oleh konsumen,

b. Persediaan barang kurang terpenuhi ,

c. Kualitas barang yang diperjual belikan kurang menarik,

Karena penyebab dari faktor- faktor tersebut maka terjadilah fluktuasi penjualan yang memberikan dampak terhadap pendapatan produsen.Seperti yang terjadi pada KDS Kamilah Wilayah Fatimatuzzahro'.

Dari hasil Observasi peneliti memang jelas terjadinya suatu fluktuasi penjualan yang terdapat di KDS Kamilah dilihat dari tidak stabilnya hasil penjualan KDS Kamilah perbulannya. Data penjualan KDS Kamilah di ketahui jumlah pendapatan pada setiap bulannya memperoleh pendapatan berkisar Rp. 30.500.000/bulan. Namun, pada bulan Februari 2018 pendapatan KDS Kamilah mengalami penurunan sekitar 40\% hingga pada bulan September 2018, pemicu penurunan pendapatan KDS Kamilah disebabkan karena banyaknya santri secara sembunyisembunyi berlangganan secara illegal pada bisnis Online. Hal demikian diketahui oleh pengurus yang ada di wilayah Fatimatuzzahro'serta mereka menuturkan kepada pengelola KDS Kamilah bahwa pemicu utama santri jarang berbelanja di KDS Kamilah ialah banyak santri yang lebih 
tertarik terhadap barang Online daripada barang yang tersedia di KDS Kamilah, sehingga pengurus mencari cara atau langkah-langkah untuk menanggulangi permasalahan tersebut. Dengan adanya langkah-langkah tersebut permasalahan yang dialami dapat sedikit teratasi, hal itu dapat diketahui dari stabilnya pendapatan KDS Kamilah hingga pada bulan Februari 2019, dengan jumlah pendapatan rata-rata sebesar Rp 30.000.000,00/bulan.

Dalam penelitian ini dapat disimpulkan bahwa berdasarkan hasil wawancara yang dilakukan peneliti diatas dari berbagai literatur yang ada seperti kepala wilayah Fatimatuzzahro', pengurus KDS Kamilah, serta santri yang berlangganan terhadap produk Online, dapat diketahui bahwa adanya dampak yang muncul dengan adanya bisnis Online yang telah masuk ke dalam pesantren khususnya di wilayah Fatimatuzzahro' serta banyaknya santri yang tertarik terhadap barang Online dari pada barang yang ada KDS Kamilah menyebabkan penurunan pendapatan perbulannya.

Dari hasil wawancara penulis dengan pengurus KDS Kamilah, didapatkan hasil wawancara tentang cara atau langkah-langkah yang dapat ditempuh oleh pengurus KDS Kamilah untuk dapat mempertahankan minat santri dalam mengkonsumsi barang-barang atau produk yang dijual oleh KDS Kamilah ialah dengan cara: Meningkatkan strategi promosi, kupon undian dan diskon harga.

a. Meningkatkan Strategi Promosi

Strategi promosi merupakan Strategi pengenalan atau popularitas suatu barang mengenai tampilan (cover), fungsi, manfaat dsb,melalui pamflet, brosur, dll sehingga barang tersebut diketahui oleh banyak orang dan orang lain merasa tertarik untuk membeli barang yang disediakan oleh suatu badan usaha. Dalam pengadaan usaha promosi yang dilakukan oleh pengurus KDS Kamilah biasanya dengan cara promosi melalui lisan maupun tulisan, pengadaan pamflet pada setiap papan informasi yang berada di wilayah sehingga mereka mengetahui dan merasa tertarik terhadap produk yang ada di jual KDS Kamilah.

b. Kupon Undian

Dalam menyelenggarakan kupon undian KDS Kamilah dengan sistematika beli barang dapat hadiah. Sistematikanya ialah dengan cara santri membeli produk/barang minimal seharga Rp 100.000,00 kemudian santri mendapatkan kupon undian, setelah pada waktu yang ditetapkan akan diumumkan pemenangnya dengan 
berbagai hadiah menarik para santri, misalnya mukenah, payung, baju, dll. Dapat dimiliki oleh para pemenang undian.adanya strategi tersebut dapat menunjang kestabilan pendapatan KDS Kamilah dan minat santri untuk mengkonsumsi barang yang disediakan oleh KDS Kamilah, selain itu manfaat lainnya ialah menarik simpati orang luar (non santri) untuk berbelanja di KDS Kamilah.

Diskon harga ialah suatu peristiwa potongan harga terhadap suatu barang. Sistematikanya dengan cara harga suatu barang dipotong beberapa persen sehingga harga suatu barang yang melambung tinggi menjadi lebih rendah sebelumnya. Dimisalkan harga suatu barang sebesar Rp 250.000,00 kemudian mengalami potongan harga sebesar 30\% hingga harga akhir menjadi Rp 175.000,00. Potongan harga tersebut merupakan langkah yang dilakukan oleh pengurus KDS Kamilah untuk bisa menarik simpati para santri serta memberi kemudahan santri untuk lebih hemat lagi berbelanja tanpa melalui via Online.

\section{KESIMPULAN}

Berdasarkan hasil penelitian dan pembahasan pada bab sebelumnya, penulis dapat menarik beberapa kesimpulan diantaranya:

1. Dampak yang ditimbulkan dari menjamurnya penjualan Online, adalah menurunnya pendapatan KDS Kamilah. Hal ini terbukti dari laporan bulanan penjualan KDS Kamilah.

2. Langkah-langkah yang dilakukan pengurus KDS Kamilah untuk menanggulangi permasalahan penurunan pendapatan yang berdampak pada fluktuasi penjualan KDS Kamilah dengan cara : meningkatkan strategi promosi, kupon undian dan diskon harga. Adanya langkah-langkah tersebut dapat memberikan perbaikan terhadap kestabilan pendapatan dan penjualan KDS Kamilah serta menarik perhatian para santri untuk lebih memilih produk yang disediakan KDS Kamilah dari pada penjualan Online. 


\section{DAFTAR PUSTAKA}

2, Rosian Anwar 1 Wijaya Adidarma, 'PENGARUH KEPERCAYAAN DAN RISIKO

PADA MINAT BELI BELANJA ONLINE', Jurnal Manajemen Dan Bisnis Sriwijaya, 14 (2016), 155-68

Adhi Iman Sulaiman, M. Maslukin, C. Chusmeru, Sri Pangetuti, 'Pemberdayaan Koperasi Pondok Pesantren Sebagai Pendidikan Sosial Dan Ekonomi Santri', Pendidikan Dan Pemberdayaan Masyarakat, 3 (2016), 109-21

Chandra, Andika, and S R R Retno, 'KECIL PADA SEKTOR FORMAL DAN

INFORMAL DI JAWA TIMUR', Bisnis, Program Manajemen Manajemen, Program

Studi Petra, Universitas Kristen Petra, 2 (2014)

Djakfar, Muhammad, Hukum Bisnis: Membangun Wacana Integrasi Perundangan Nasional Dengan Syariah (UIN-Maliki Press, 2016)

Hadi, Sutrisno, 'Metode Research Jilid II, Yogyakarta', Andi Offset, 1992

Kharis, Ismu Fadli, 'Studi Mengenai Impulse Buying Dalam Penjualan Online', Skripsi. Semarang: Universitas Diponegoro, 2011

Lexy, J Moleong, 'Metodologi Penelitian Kualitatif', Bandung: Remaja Rosdakarya, 2002

Nurul Jannah, Sholihatin, 'Analisis Open Order Dan Close Order Terhadap Minat Beli Produk Online Shop Studi Pada SNJCOLLECTION', Kompetensi, 11 (2017), 244-55

Shobirin, JUAL BELI DALAM PANDANGAN ISLAM Jurnal Bisnis dan Menejemen Islam, Vol.3, No.2, Desember 2015, 259.

Yuliana, Oviliani Yenty, 'PENGGUNAAN TEKNOLOGI INTERNET', 2 (2000), 36-52

Moh Idil Ghufron and Inas Fahmiyah, 'KONSEP WARALABA PERSPEKTIF

EKONOMI ISLAM', Amwaluna: Jurnal Ekonomi Dan Keuangan Syariah, 3.1 (2019). 
